\title{
Analysis of Some Factors that Influence Length of Stay of Anemia Patients in Installation of Inpatient Regional Public Hospital Karawang in 2020
}

\author{
Dwi Bayu Wikarta ${ }^{1}$, Alih Germas Kodyat ${ }^{1}$, Cicilia Windiyaningsih ${ }^{1}$, \\ Fitra Hergyana ${ }^{1}$
}

${ }^{1}$ Hospital Administration Management, University of Respati Indonesia, Jakarta

Corresponding Author: Dwi Bayu Wikarta

DOI: https://doi.org/10.52403/ijrr.20220205

\begin{abstract}
Objective: To determine factors related to the length of stay in anemic patients who are being hospitalized at the Karawang Hospital.

Methods: This was a cross-sectional study with cohort-retrospective design. This study was analyzed quantitatively. Data for this study was obtained from medical record data.

Result: This study showed that most anemic patients were treated with a length of stay of less than 6 days, with an overall average length of stay of 6.31 days. Most of the samples were treated with severe degree of anemia. Hemoglobin value at discharge has an effect on the length of stay, while the other variables have no significant effect statistically.

Conclusion: Description of the length of hospitalization in this study was in accordance with the target from the Ministry of Health. This was influenced by the quality control and financing applied, the blood bank facilities that contributed very well, and the transfusion process carried out directly by the nurses.
\end{abstract}

Keyword: Length of stay, Anemia.

\section{INTRODUCTION}

One of the parameters related to the quality of health care in hospitals is the length of hospitalization. Anemia was common among the general medical inpatient cohort, and it was found that anemic patients, compared with non-anemic patients, had a longer mean and median length of stay. In 2020, there were 1,824 anemic patients being hospitalized at the Karawang Hospital, with the average length of hospitalization was 12 days.

This study aims to determine factors that associated with the length of stay for hospitalized anemic patients at the Karawang Hospital. Theoretically, the length of hospitalization is influenced by internal and external factors. Internal factors consist of medical (comorbidities, Hb value at admission, $\mathrm{Hb}$ value at discharge, blood type, age, gender, routine drugs consumption) and administration (day of admission, and day of discharge). While external factors include healthcare cost guarantor and reasons of discharge. The aim of this study is to know the influencing factors that will improve healthcare of anemic patients effectively and efficiently.

\section{METHODS}

This was a cross-sectional study with cohort retrospective design and quantitative analysis. The study was conducted in inpatient room at Karawang Hospital. The population in this study were all medical records of anemic patients that were hospitalized between January to December 2020. There were 42 samples of anemic patients in this study according to that period. Data was collected using checklists until the required number of samples was met. The data was analyzed and tested statistically. The data was edited 
and coded, and then it was put in tables based on the independent variables with one dependent variable which is patient length of stay. The analysis in this study used frequency distribution methods, chi square test, independent $\mathrm{t}$ test and if necessary, logistic regression test is performed. It was significant if the $\mathrm{p}$ value $<0.05$.

\section{RESULT AND DISCUSSION}

There were 42 anemic patients participated in this study. Table 1.1 shows the characteristics of the respondents.

Table 1.1 Basic characteristics of study subjects

\begin{tabular}{|c|c|}
\hline Variable & Number \\
\hline \multicolumn{2}{|l|}{ Gender (n) } \\
\hline Male & $15(35,7 \%)$ \\
\hline - $\quad$ Female & $27(64 \%)$ \\
\hline Age (years) & $44,79 \pm 17,29$ \\
\hline $\begin{array}{l}\text { Age criteria } \\
<60 \text { years } \\
\geq 60 \text { years }\end{array}$ & $\begin{array}{c}33(78,6 \%) \\
9(21,4 \%)\end{array}$ \\
\hline $\begin{array}{l}\text { Occupation } \\
\text { Employee } \\
\text { Unemployee }\end{array}$ & $\begin{array}{l}14(33,3 \%) \\
28(66,7 \%)\end{array}$ \\
\hline $\begin{array}{c}\text { Cost guarantor } \\
\text { Personal } \\
\text { Third party } \\
\end{array}$ & $\begin{array}{c}8(19 \%) \\
34(81 \%)\end{array}$ \\
\hline $\begin{array}{l}\text { Admission } \\
\text { Workdays } \\
\text { Holidays } \\
\end{array}$ & $\begin{array}{l}28(66,7 \%) \\
14(33,3 \%)\end{array}$ \\
\hline $\begin{array}{l}\text { Discharge } \\
\text { Workdays } \\
\text { Holidays } \\
\end{array}$ & $\begin{array}{c}40(95,2 \%) \\
2(4,8 \%)\end{array}$ \\
\hline \multicolumn{2}{|l|}{ Comorbidities } \\
\hline Yes & $30(70 \%)$ \\
\hline$-\quad \mathrm{No}$ & $12(30 \%)$ \\
\hline Transfusion & $42(100 \%)$ \\
\hline Blood bank availability & $42(100 \%)$ \\
\hline Transfusion nurse & $42(100 \%)$ \\
\hline Hemoglobin value & $5,88 \pm 2,30 \mathrm{~g} / \mathrm{dl}$ \\
\hline \multicolumn{2}{|l|}{ Anemia severity } \\
\hline Severe & $24(57,1 \%)$ \\
\hline - $\quad$ Moderate & $18(42,9 \%)$ \\
\hline \multicolumn{2}{|l|}{ Blood type } \\
\hline $\mathrm{A}$ & $12(28,6 \%)$ \\
\hline $\mathrm{B}$ & $8(19 \%)$ \\
\hline $\mathrm{AB}$ & $3(7,1 \%)$ \\
\hline $\mathrm{O}$ & $19(45,2 \%)$ \\
\hline \multicolumn{2}{|l|}{ History of medication } \\
\hline Yes & $25(59,5 \%)$ \\
\hline No & $17(40,5 \%)$ \\
\hline Length of stay & $6,31 \pm 4,19$ \\
\hline \multicolumn{2}{|l|}{ Length of stay criteria } \\
\hline$<6$ days & $23(54,8 \%)$ \\
\hline$\geq 6$ days & $19(45,2 \%)$ \\
\hline Discharge by doctor & $42(100 \%)$ \\
\hline Hb value at discharge & $9,05 \pm 0,97 \mathrm{~g} / \mathrm{dl}$ \\
\hline
\end{tabular}

In this study, most anemic patients were often treated with a length of stay of less than 6 days $(54.8 \%)$, with an average LOS of 6.31 days. Previous study by
Richard J Lind et al (2013) showed an average length of stay of 6.47 days. Another study by Maria Luigne et al (2020) showed an average length of stay of 10 days, a study by Bruce F Culleran et al (2006) showed an average length of stay of 8 days, and another study by Michael C Reade et al (2013) showed an average length of stay of 7.3 days.

This study was dominated by severe anemia patients. One comparative study that also assessed the severity of anemia is from Maria Luigne et al (2020) study that found patients with $49 \%$ anemia, $14.8 \%$ severe anemia, and $35.9 \%$ mild anemia. From this comparison, it was found that the most frequent criteria for anemia were anemia in the severe category. In this study, a lower $\mathrm{Hb}$ value had a shorter length of stay. This result was different from previous study which Richard J Lind et al(2013), Maria Luigne et al (2020), Bruce F Culleran et al (2006), Michael C Reade et al (2013) got that the lower hemoglobin value resulting in longer the length of stay. The most common blood type was type O. However, after further analysis regarding its correlation to patient length of stay, there was no significant effect found. This result was not comparable with previous studies since there was no discussion about blood type.

The average age of the patient was 44.79 years, but patients age had no significant effect on length of stay. This was different compared to previous studies by Richard J Lind et al (2013), Maria Luigne et al (2020), Bruce F Culleran et al (2006), Michael C Reade et al (2013). Previous study showed that older age had longer length of stay.

Characteristic of the respondent showed most of the patients in this study were female, but there was no correlation between gender and patient LOS. This result was similar with previous study by Richard J Lind et al (2013), Maria Luigne et al(2020), Bruce F Culleran and colleagues (2006), Michael C Reade and colleagues (2013). 
Dwi Bayu Wikarta et.al. Analysis of some factors that influence length of stay of anemia patients in installation of inpatient regional public hospital Karawang in 2020.

Table 1.2 Effect of Independent Variables on Length of Stay

\begin{tabular}{|c|c|c|c|c|c|c|c|c|c|}
\hline \multirow[b]{3}{*}{ No } & & & \multicolumn{4}{|c|}{ Length of Hospitalization } & & \multirow{2}{*}{\multicolumn{2}{|c|}{ OR 95\% CI }} \\
\hline & & & \multicolumn{2}{|c|}{$<6$ days } & \multicolumn{2}{|c|}{$\geq 6$ days } & & & \\
\hline & \multicolumn{2}{|c|}{ Variables } & $\mathbf{n}$ & $\%$ & $\mathbf{n}$ & $\%$ & P value & lower & upper \\
\hline \multirow[t]{2}{*}{1} & \multirow[t]{2}{*}{ Gender } & Male & 8 & 53,3 & 7 & 46,7 & \multirow[t]{2}{*}{0,572} & \multirow{2}{*}{\multicolumn{2}{|c|}{$0,914(0,258-3,246)$}} \\
\hline & & Female & 15 & 55,6 & 12 & 44,4 & & & \\
\hline \multirow[t]{2}{*}{2} & \multirow[t]{2}{*}{ Age } & $<60$ years old & 18 & 54,5 & 15 & 45,5 & \multirow[t]{2}{*}{0,629} & \multirow{2}{*}{\multicolumn{2}{|c|}{$0,960(0,218-4,228)$}} \\
\hline & & $\geq 60$ years old & 5 & 55,6 & 4 & 44,4 & & & \\
\hline \multirow[t]{2}{*}{3} & \multirow[t]{2}{*}{ Occupation } & Unemployed & 15 & 53,6 & 13 & 46,4 & \multirow[t]{2}{*}{0,545} & \multirow{2}{*}{\multicolumn{2}{|c|}{$1,15(0,32-4,21)$}} \\
\hline & & Employed & 6 & 75 & 2 & 25 & & & \\
\hline 4 & Cost Guarantor & Third party & 17 & 50 & 14 & 50 & 0,190 & 3,00 & $3-17,02)$ \\
\hline \multirow[t]{2}{*}{5} & \multirow[t]{2}{*}{ Admission } & Workdays & 14 & 50 & 14 & 50 & \multirow[t]{2}{*}{0,29} & \multirow{2}{*}{\multicolumn{2}{|c|}{$0,56(0,148-2,08)$}} \\
\hline & & Holidays & 9 & 64,3 & 5 & 35,6 & & & \\
\hline \multirow[t]{2}{*}{6} & \multirow[t]{2}{*}{ Discharged } & Workdays & 23 & 57,5 & 17 & 42,5 & \multirow[t]{2}{*}{0,199} & \multirow{2}{*}{\multicolumn{2}{|c|}{$0,425(0,296-0,609)$}} \\
\hline & & Holidays & 1 & 0,0 & 2 & 100,0 & & & \\
\hline \multirow[t]{4}{*}{7} & \multirow{4}{*}{ Blood type } & $\mathrm{A}$ & 7 & 58,3 & 5 & 41,7 & 0,448 & \multicolumn{2}{|c|}{$0,35(0,025-5,11)$} \\
\hline & & $\mathrm{B}$ & 3 & 37,5 & 5 & 62,5 & 0,898 & \multirow{2}{*}{\multicolumn{2}{|c|}{$0,83(0,051-13,63)$}} \\
\hline & & $\mathrm{O}$ & 12 & 63,2 & 7 & 36,8 & 0,348 & & \\
\hline & & $\mathrm{AB}$ & 1 & 33,3 & 2 & 66,7 & & & \\
\hline \multirow[t]{2}{*}{8} & \multirow[t]{2}{*}{ Comorbidities } & With & 17 & 56,7 & 13 & 43,4 & 0,742 & $1,31(($ & $2-5,001)$ \\
\hline & & Without & 6 & 50 & 6 & 50 & & & \\
\hline 9 & Severity & Moderate & 11 & 61,1 & 7 & 38,9 & 0,344 & 1,571 & $55-5,43)$ \\
\hline & & Severe & 12 & 50 & 12 & 50 & & & \\
\hline 10 & History of Medication & Yes & 15 & 60 & 10 & 40 & 0,531 & 1,688 & $36-5,854)$ \\
\hline & & No & 8 & 47,1 & 9 & 52,9 & & & \\
\hline
\end{tabular}

In this study, patients with a low $\mathrm{Hb}$ mean value were associated with comorbidities $\mathrm{p}$ $0.018(\mathrm{p}<0.05)$ which is described in the table below.

Table 1.3 Differences in hemoglobin values at admission based on comorbidities

\begin{tabular}{|l|c|c|c|c|c|}
\hline Hb value at admission & n & Mean & SD & T (t-test) & P-value \\
\hline With Comorbidities & 30 & 5,36 & 2,26 & \multirow{2}{*}{$-2,47$} & 0,018 \\
\hline Without Comorbidities & 12 & 7,2 & 1,92 & & \\
\hline
\end{tabular}

This result was similar to previous studies which also stated that anemic patients with comorbidities had lower $\mathrm{Hb}$ values. However, this did not affect the length of stay. This result was different from previous study by Richard $\mathrm{J}$ Lind et al (2013), Maria Luigne et al (2020), Bruce F Culleran et al (2006), Michael C Reade et al (2013). Previous study showed that patient length of stay will be longer in patient with comorbidities. The majority of days of admission and discharge occurred on working days and did not affect the length of stay. This result could not be compared with other studies because the lack of similar topic related to this variable. Haemoglobin value at discharge showed a significant difference, which was lower in patients with a length of stay $<6$ days compared to a length of stay of more than 6 days, with a $\mathrm{p}$ value of $0.008(\mathrm{p}<0.05)$ (as presented in table below.

Table 1.4 Differences in hemoglobin values at discharge based on length of stay

\begin{tabular}{|c|c|c|c|c|c|}
\hline Hb value at discharge & $\mathbf{n}$ & Mean & Sum & T (Mann-Whitney test) & P-value \\
\hline Length of stay $<6$ days & 23 & 17,02 & 391,5 & \multirow{2}{*}{115,5} & 0,008 \\
\hline Length of stay $\geq 6$ days & 19 & 26,92 & 511,5 & & \\
\hline
\end{tabular}

The average haemoglobin value at discharge was 9.49, which was lower compared to previous study by Richard $\mathbf{J}$ Lind et al (2013) in which the average $\mathrm{Hb}$ value at discharge was $11.7 \mathrm{~g} / \mathrm{dl}$. Further study is needed to find the cause of various results related to the $\mathrm{Hb}$ value on discharge variable.
In this study, it was found that most of the study samples were treated according to the target length of stay, which was less than 6 days, and it was in accordance with the recommendation from the Ministry of Health. This was due to the implementation of cost control and quality control that has been running very well, undetermined discharge criteria, blood bank availability 
factors, and health worker factors was also contribute, because all patient transfusion actions in this study so that the transfusion process was guaranteed and not hampered.

\section{CONCLUSION AND SUGGESTION}

The conclusions of this study include the description of the length of stay for anemic research. patients treated most often was less than 6 days, with an overall average length of stay of 6.31 days. The description of the severity of the patient was dominated by patients with a degree of severe anemia. The average hemoglobin value at admission was $5.88 \pm 2.30 \mathrm{~g} / \mathrm{dl}$, but there was no effect of the hemoglobin value at admission on the length of stay. The most blood type was blood type $\mathrm{O}$, but blood type does not affect the length of stay. The mean age in this study was $44.79 \pm 17.29$ years, but age did not affect the length of stay.

This study was dominated by female, but there was no effect of gender on the length of stay. The sample of this study was mostly had comorbidities, and the most frequent comorbidities were melena or gastrointestinal bleeding. However, from the results of the analysis, there was no effect of comorbidities on the length of stay. Days of admission and discharge of the study samples often occur on weekdays. However, there was no effect on the length of stay. The suggestions include, For hospital management, cost control that has been implemented and is currently running is maintained and evaluated periodically. It is also necessary to make clinical pathways and clinical practice guidelines specifically for anemic patients to maintain the quality. For the doctor in charge, to give suggestions to the management for a policy to improve disease controls and healthcare to the maximum quality. For researchers, there is a need to analyze larger sample and compare the sample with the non-anemic group for the better.

\section{Acknowledgement: None}

Conflict of Interest: None

\section{Source of Funding: None}

\section{Ethical Approval: Approved}

\section{REFERENCES}

1. Afif, Ahmad (2008). Hubungan Faktor Komorbid, Usia dan Status Gizi dengan Lama Rawat Inap pada Pasien Hernia Inguinalis Lateralis Reponibilis yang Dioperasi Herniorepair Tanpa Mesh di RS PKU Muhammadiyah Surakarta Periode 2005 - 2007.

2. Bakta IM. Pendekatan Terhadap Pasien Anemia. Dalam: Sudoyo AW, Setiyohadi B, Alwi I, Simadibrata M, Setiati S (editor). Buku ajar Ilmu Penyakit Dalam jilid I. Edisi ke-4. Jakarta: Pusat Penerbitan Departemen Ilmu Penyakit Dalam FKUI 2009;632-5.

3. Bross MH, Soch K, Smith-Knuppel T. Anemia in older persons. Am Fam Physician 2010; 82: 480-487.

4. Culleton, B.F.; Manns, B.J.; Zhang, J.;Tonelli, M.; Klarenbach, S.; Hemmelgarn, B.R. Impact of anemia on hospitalization and mortality in older adults. Blood 2006, 107, 3841-3846

5. Departemen Kesehatan RI (2005). Standar Pelayanan Minimal, Direktorat Jenderal Bina Kesehatan Masyarakat. Jakarta.

6. Dharmarajan TS, Avula S, Norkus EP. Anemia increases risk for falls in hospitalized older adults. J Am Med Dir Assoc 2006; 7: 287-293.

7. Goddard AF, James MW, McIntyre AS, et al. Guidelines for the management of iron deficiency anemia. Gut 2011; 60: 1309-16. [PubMed: 21561874]

8. Iezzoni, Lisa I, Michael DP (2012). Patient's Perspective: Hard Lessons from a Long Hospital Stay. American Journal of Nursing, volume 112, April 2012

9. Lin RJ, Evans AT, Chused AE, E Michele, and Unterbrink. Anemia in General Medical Inpatients Prolongs Length of Stay and Increases 30-day Unplanned Readmission Rate. South Med J. 2013 May;106(5):316320. doi:10.1097/SMJ.0b013e318290f930

10. Proverawati, A. 2013. Anemia dan Anemia Kehamilan. Yogyakarta: Nuha Medika.

11. Randi ML, Bertozzi I, Santarossa C, Cosi E, Lucente F, Bogoni G, et al. Prevalence and Causes of Anemia in Hospitalized Patients: 
Dwi Bayu Wikarta et.al. Analysis of some factors that influence length of stay of anemia patients in installation of inpatient regional public hospital Karawang in 2020.

Impact on Diseases Outcome. J. Clin. Med. 2020, 9, 950; doi:10.3390/jcm9040950

12. Thavendiranathan P, Bagai A, Ebidia A, et al. Do blood tests cause anemia in hospitalized patients? The effect of diagnostic phlebotomy on hemoglobin and hematocrit levels. J Gen Intern Med 2005; 20: 520-4. [PubMed: 15987327]

13. Victorian Auditor General. Hospital Performance: Length of Stay. Victorian Government Printer 2016: PP No 128, Session 2014-16.

14. Wartawan IW (2012). Analisis Lama Hari Rawat Pasien Yang Menjalani Pembedahan Di Ruang Rawat Inap Bedah Kelas III RSUP Sanglah Denpasar Tahun 2011. FKM UI.

15. World Health Organization, 2014. Haemoglobin Concentrations for The Diagnosis Of Anemia And Assessment Of
Severity. Vitamin and Mineral Nutrition Information System.Tersedia: http://www.who.int/vmnis/indicators/haemo globin.pdf.

16. Young JB, Abraham WT, Albert NM, et al. Relation of low hemoglobin and anemia to morbidity and mortality in patients hospitalized with heart failure (insight from the OPTIMIZE-HF registry). Am J Cardiol 2008; 101: 223-30. [PubMed: 18178411]

How to cite this article: Dwi Bayu Wikarta, Alih Germas Kodyat, Cicilia Windiyaningsih et.al. Analysis of some factors that influence length of stay of anemia patients in installation of inpatient regional public hospital Karawang in 2020. International Journal of Research and Review. 2022; 9(2): 23-27. DOI: https://doi.org/ 10.52403/ijrr.20220205 